\title{
CHARACTERISATION OF PHYSICAL AND BIOCHEMICAL TRAITS OF HULLESS SPRING BARLEY GRAIN IN THE LATVIAN BREEDING PROGRAMME
}

\author{
Māra Bleidere*, Sanita Zute*, and Ida Jākobsone** \\ * State Stende Cereals Breeding Institute, Dižstende, "Dižzemes", LV-3258, LATVIA; \\ sanita.zute@stendeselekcija.Iv \\ ${ }^{* *}$ Faculty of Chemistry, University of Latvia, Kr. Valdemāra iela 48, Rīga LV-1013, LATVIA; \\ ida.jakobsone@lu.lv
}

Communicated by Daina Kārkliṇa

\begin{abstract}
Incorporation of whole grain, such as hulless barley, as a part of a balanced diet can help reduce the risk of coronary heart diseases, diabetes and specific cancers, and provide other health benefits as well. The objectives of this study were to determine the physical and chemical characteristics of grains of hulless barley genotypes from the Latvian spring barley programme. Field experiments were carried out in 2010-2011 at the State Stende Cereal Breeding Institute. Grain samples of 29 hulless spring barley breeding lines were analysed for grain physical traits (1000 kernel weight, test weight), macronutrients (crude protein, starch, $\beta$-glucans), and micronutrients (total phenolic content, DPPH antiradical scavenging activity and $\alpha$-tocopherol content). The variation of physical traits and macronutrients was mainly determined by genotype $\left(\omega^{2}=32-62 \%\right)$ and year $\left(\eta^{2}=8-42 \%\right)$ and to a lesser extent by interaction of factors. The difference between hulless genotypes, as indicated the coefficient of variation, was rather high for all micronutrients $(V \%=13.4-25.6)$. Significant $(\mathrm{P}<0.05)$ positive correlation was detected between radical scavenging activity and total phenolic content $(r=0.519)$ and starch content $(r=0.530)$. The best hulless breeding lines '1185' and 'IC 360' (variety 'Kornelija' submitted for DUS and VCU tests) were selected for future usage in clinical investigations.
\end{abstract}

Key words: hulless barley, physical and chemical traits, total phenolic content, scavenging activity, $\alpha$-tocopherol.

\section{INTRODUCTION}

Although barley (Hordeum vulgare L.) has a long history as food, it must compete with oats, rice, and wheat, which are already well-accepted food commodities in the market. At present, extensive food research has demonstrated the versatility and adaptability of barley for much more food products than pearled barley. The advent of new barley varieties, starch types, and hulless genotypes has presented to the cereal food industry an opportunity to develop new barley products, which are exciting and have many health benefits (Newman and Newman, 2008).

In covered barley, the flowering glumes are fused and adhere strongly to seed with a cementing substance. In hulless barley, fusion of the flowering glumes does not occur and the hull falls off during threshing (Bhatty, 1999). The seed coat of hulless barley is loosely attached and easily removed during harvesting, resulting in grain with a test weight and physical appearance similar to wheat (Evers and Millar, 2002).
Kernel size or plumpness can become important measures of quality in food barley. Plump grains contain significantly more starch, less protein, and less fibre than thin kernels. Barley kernels vary widely in size due to genotype, position on the spike, and environmental growing conditions. Typical hulless kernels usually weigh between 25 and $35 \mathrm{mg}$ (Newman and Newman, 2008). Thousand kernel weight provides a measure of average kernel weight, and this criterion is widely used in barley breeding to describe grain plumpness.

Comparison of covered and hulless barley has shown that the later generally contains more protein, starch and $\beta$-glucan. This is due to removal of the fibrous hull, which has a dilution effect on these components (Bhatty, 1999). Two large-molecular-weight polysaccharide soluble fibres (arabinoxilan and $\beta$-glucan) are structural components of the thick cell walls of the aleirone. The cell walls of the starchy endosperm contain the same two polysaccharides found in the cell walls of the aleirone tissue, but the amount of $\beta$-glucan is greater than of arabinoxilan (Newman and 
Newman, 2008). Barley kernels contain high levels of $\beta$-glucans, and much of the research on the health-promoting properties of barley has focused on mechanisms involving $\beta$-glucans (Pins and Kaur, 2006).

The interest in the role of natural antioxidant compounds in human health has increased recently. Barley grains in general contain different types of phytochemicals, which are sometimes referred to as phytonutrients, and in barley the most studied compounds are sterols, tocopherols, tocotrienols and phenolic compounds (Newman and Newman, 2008). Phenolic compounds are considered as a major group of compounds that contribute to the antioxidant activity of cereal and are considered with great interest for the development of functional foods. The antioxidant activity of polyphenols has been reported to be mainly due to their redox properties, which can play an important role in neutralising free radical and quenching oxygen or decomposing peroxides (Kahkonen et al., 1999).

Vitamin E is a complex of eight izomers, four tocopherols and four tocotrienols, collectively called tocols. The tocols are associated with lipid components in aleirone, endosperm, and embryo tissue (Newman, Newman, 2008). The tocols in barley germ are predominantly tocopherols (about 97\%), whereas those in the endosperm are predominantly tocotrienols (80-90\%). Therefore, the total amounts of tocotrienols are greater than those of tocopherols in barely oil prepared from ground barley kernels (Charalampopouos et al., 2002; Moreau et al., 2007). Both genotype and environment affect total tocol content (Cavarello et al., 2004). Specific forms of tocopherols and tocotrienols accumulate with different kinetics during barley grain development (Falk et al., 2004).

The objective of this study was to describe the physical and chemical characteristics of grains of hulless barley genotypes from the Latvian spring barley programme.

\section{MATERIALS AND METHODS}

Grain samples of 29 hulless spring barley breeding lines of Latvian origin were studied, including 26 lines from breeding programmes of the State Stende Cereals Breeding Institute (Stende) and three lines from the State Priekuli Plant Breeding Institute (Priekulii). One line with waxy endosperm from Priekuḷi was characterized.

Field experiments were carried out at the State Stende Cereal Breeding Institute for two seasons during 2010-2011. The soil was sod-podzolic sandy loam with humus content 21 (2010)-24 (2011) $\mathrm{mg} \mathrm{kg}^{-1}$, soil pH KCl 5.4 (2010) 5.8 (2011), available phosphorus $\mathrm{P}_{2} \mathrm{O}_{5} \quad 137.0$ (2010) 158.8 (2011) $\mathrm{mg} \mathrm{kg}^{-1}$, and potassium $\mathrm{K}_{2} \mathrm{O} 211.0$ (2010) 175.7 (2011) $\mathrm{mg} \mathrm{kg}^{-1}$. The pre-crop in both years of investigation was a mixture of peas and spring wheat. The barley was sown with a compact trial drill 'Hege 80' in a well prepared seedbed at a rate of 500 germinating seeds per $\mathrm{m}^{2}$. The yield was harvested by a combine 'Hege 140'.
The following grain physical traits were evaluated: 1000 kernel weight/TKW (g) by ISTA method, test weight/TW $\left(\mathrm{g} \mathrm{L}^{-1}\right)$ by automatic grain analyser Infratec Analysis 1241. Macronutrients crude protein content/CP $\left(\mathrm{g} \mathrm{kg}^{-1}\right)$, starch content/ST $\left(\mathrm{g} \mathrm{kg}^{-1}\right)$, $\beta$-glucans content/BGL $\left(\mathrm{g} \mathrm{kg}^{-1}\right)$ were determined by an automatic grain analyzer Infratec Analysis 1241.

For the determination of total phenolic content (TPC) and radical scavenging activity (RSA), 1.5 gram grain flour was mixed with $30 \mathrm{ml}$ of $50 \%$ (vol.) ethanol in an Erlenmeyer flask $(250 \mathrm{ml})$. The mixture was stirred at $40{ }^{\circ} \mathrm{C}$ for $15 \mathrm{~min}$ utes and then at room temperature for an hour. After extraction the supernatant was filtered through filter paper. The filtrate was used for the analysis of TPC and RSA.

TPC was determined according to colorimetric method described in literature (Ragaee et al., 2006) with some modifications. This method is based on the reduction of the FolinCiocalteu reagent by phenol to a mixture of the reaction products, having absorbance maximum at $765 \mathrm{~nm} .1 \mathrm{ml}$ of extract was mixed with $5 \mathrm{ml}$ of $10 \%$ Folin-Ciocalteu's reagent in distilled water and $4 \mathrm{ml} 7.5 \% \mathrm{Na}_{2} \mathrm{CO}_{3}$ solution, stirred for $30 \mathrm{~min}$ at room temperature and the absorbance at $765 \mathrm{~nm}$ was measured with a spectrophotometer UVIKON 930 (Kontron Instruments, Italy). TPC was calculated using gallic acid as a standard $(0.0075-0.060 \mathrm{mg} / \mathrm{mL})$ $\left(\mathrm{R}^{2}=0.9999\right)$ and expressed as $\mathrm{mg}$ gallic acid equivalents per $100 \mathrm{~g}$ of grain dry weight (DW).

2.2-diphenyl-1-picrylhydrazyl (DPPH) radical scavenging activity (RSA) assay was performed according to the modified method prescribed in literature (Ragaee et al., 2006). $0.4 \mathrm{ml}$ of extract (sample) or 50\% (vol.) ethanol (control sample) was added to $3.6 \mathrm{ml}$ of $10^{-4} \mathrm{M}$ DPPH solution in ethanol and mixed. The mixture was vigorously shaken and left to stand for $20 \mathrm{~min}$. The absorbance at $517 \mathrm{~nm}$ was measured against 50\% (vol.) ethanol as a blank. The DPPH radical scavenging activity (\%) was calculated using equation (1):

$\operatorname{RSA}(\%)=\frac{\left(A_{\text {control }}-A_{\text {sample }}\right)}{A_{\text {control }}} \cdot 100 \%$ where

$\mathrm{A}_{\text {control }}$ is the absorbance of the control sample; $\mathrm{A}_{\text {sample }}$ is the absorbance of the sample.

Mean samples from all replications were taken and milled for $\alpha$-tocopherol $(\alpha-\mathrm{T})$ determination in the Laboratory of Food and Environmental Investigations Institute of Food Safety, Animal Health and Environment "BIOR" using the high-performance liquid-chromatography method. The method is a standard for detection of $\alpha$-tocopherol in diet samples. Absorption was measured at $292 \mathrm{~nm}$. Chromatography was carried out on a C18 column using methanol/ water $(98 / 2 \mathrm{v} / \mathrm{v})$.

The growing seasons of 2010 and 2011 were characterised by temperature above to the long-term average and some extreme periods of drought. In 2010, low precipitation and 
high temperature occurred in the third decade of June and the first decade of July. In 2011, hot and dry conditions occurred during the third decade of May and in first decade of June.

ANOVA were used for statistical data analysis. The obtained results were statistically processed using methods of descriptive statistics. In the analysis of variance omega squared $\left(\omega^{2}\right)$ was calculated to measure the effect size or relative contributions of factors (genotype, year, genotype $\times$ year) using equation (2) (Grissom and Kim, 2012.):

$\omega^{2}=\left[\mathrm{SS}_{\text {Effect }}-\left(\mathrm{df}_{\text {Effect }}\right)\left(\mathrm{MS}_{\text {Residual }}\right)\right] /\left(\mathrm{SS}_{\text {Total }}+\mathrm{MS}_{\text {Residual }}\right)$.

The significance of the effect of factors was determined at probability level of 0.05 . The value of genotypic variability for traits was determined and expressed by standard deviation (s) and coefficient of variations (V\%) values. Pearson correlation coefficients between two year phenotypic means were calculated. The best lines according to food grain physical and chemical traits were selected using selection criterion - trait values $\geq$ mean $+s$.

\section{RESULTS}

Physical traits of grain. ANOVA showed that physical traits of grain for hulless barley lines in the tested breeding material were significantly $(P \leq 0.05)$ influenced by two main factors (genotype, year) and their interaction (Fig. 1).

The variation of thousand kernel weight (TKW) was mainly determined by genotype $\left(\omega^{2}=52 \%\right)$ and year $\left(\omega^{2}\right.$ hulled $=$ $31 \%$ ). TKW for hulless barley breeding lines was 40.7 and $43.8 \mathrm{~g}$ in 2010 and 2011, respectively. Significantly higher $(P \leq 0.05)$ values of this trait were observed in 2011 , but a greater difference between minimum and maximum value of this traits was found in 2010, as indicated also coefficient of variation (Table 1). In both years, some hulless breeding lines had significantly higher TKW than those of the hulless standard variety 'Irbe' (+3.9 and 6.9 g compared with hulless standard variety 'Irbe'; $\mathrm{Rs}_{0.05}=1.39-1.81 \mathrm{~g}$ ).

The main effect of variation of TW was due to year and genotype ( $42 \%$ and $32 \%$, respectively) and to a lesser extent

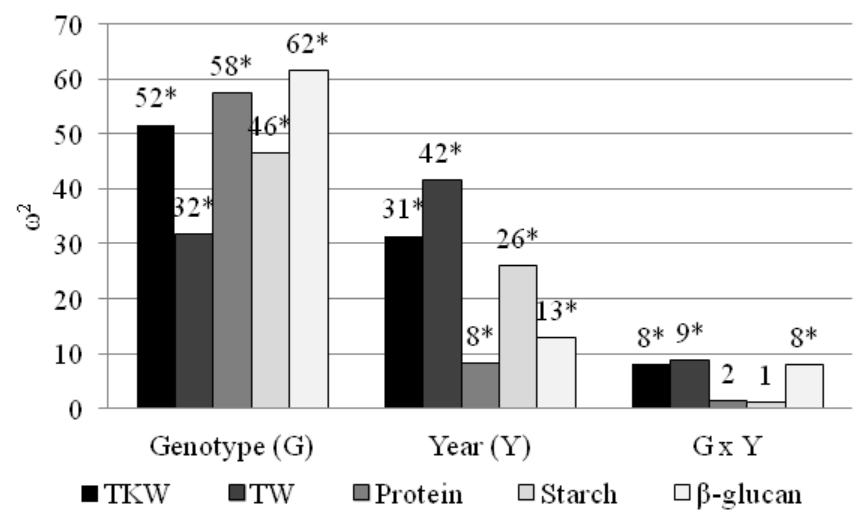

Fig. 1. Relative contribution of factors for hulless barley grain quality traits $\left({ }^{*} P \leq 0.05\right)$ (TKW, thousand kernel weight, TW, test weight).

by interaction of factors for both physical traits (Fig. 1). There was a significant $(P \leq 0.05)$ difference between years of investigation in mean value of TW for hulless breeding lines, and a higher test weight was observed in 2010 (Table 1). Grains of hulless genotypes were characterised by higher TW than that of hulled barley standard variety 'Ansis'. The best hulless breeding lines, according to TW value, were on the level of that of standard 'Irbe'.

Macronutrient content. ANOVA indicated that the variation of all macronutrients (crude protein, starch and $\beta$-glucan) content was mainly determined by genotype $\left(\omega^{2}=46-62 \%\right)$ and to a lesser extent by year and by interaction of factors (Table 1).

The difference between minimum and maximum value of crude protein was rather high and varied from 133.0 to $188.2 \mathrm{~g} \mathrm{~kg}^{-1}$ in 2010 and from 145.1 to $183.2 \mathrm{~g} \mathrm{~kg}^{-1}$ in 2011. A significantly higher crude protein for grain of hulless barley lines was observed in 2011. In both years, there were some hulless breeding lines with significantly higher crude protein content $\left(+30.4-47.9 \mathrm{~g} \mathrm{~kg}^{-1}\right.$, compared to the hulless standard variety 'Irbe'; $\mathrm{Rs}_{0.05}=14.25-17.32$ $\mathrm{g} \mathrm{kg}^{-1}$ ).

There was a significant $(P \leq 0.05)$ difference between years of investigation in mean value of starch content for grains

Table 1

CHARACTERISTICS OF GRAIN PHYSICAL TRAITS AND MACRONUTRIENT CONTENT FOR HULLESS SPRING BARLEY LINES AND HULLESS (HB) AND COVERED (C) STANDARDS (2010-2011)

\begin{tabular}{|c|c|c|c|c|c|c|c|c|c|c|}
\hline \multirow[t]{3}{*}{ Trait $^{1}$} & \multicolumn{5}{|c|}{2010} & \multicolumn{5}{|c|}{2011} \\
\hline & \multicolumn{3}{|c|}{ Breeding lines } & \multirow{2}{*}{$\begin{array}{c}\begin{array}{c}\text { Standards, } \\
\text { mean }\end{array} \\
\mathrm{HB} / \mathrm{C}^{2}\end{array}$} & \multirow[t]{2}{*}{$\mathrm{Rs}_{0.05}$} & \multicolumn{3}{|c|}{ Breeding lines } & \multirow{2}{*}{$\begin{array}{c}\begin{array}{c}\text { Standards, } \\
\text { mean }\end{array} \\
\mathrm{HB} / \mathrm{C}\end{array}$} & \multirow[t]{2}{*}{$\mathrm{Rs}_{0.05}$} \\
\hline & mean & $\min / \max$ & $\mathrm{V} \%$ & & & mean & $\min / \max$ & $\mathrm{V} \%$ & & \\
\hline TKW, g & $40.7 b^{3}$ & $33.9 / 44.7$ & 5.8 & $40.8 / 46.1$ & 1.39 & $43.8 \mathrm{a}$ & $38.7 / 48.8$ & 4.9 & $41.9 / 48.1$ & 1.81 \\
\hline $\mathrm{TW}, \mathrm{g} \mathrm{L}^{-1}$ & $783.8 \mathrm{a}$ & $724.8 / 808.5$ & 2.7 & $807.8 / 682.8$ & 17.88 & $749.3 b$ & $711.0 / 777.5$ & 2.0 & $764.5 / 648.5$ & 14.25 \\
\hline $\mathrm{CP}, \mathrm{g} \mathrm{kg}^{-1}$ & $153.0 \mathrm{~b}$ & $133.0 / 188.2$ & 6.4 & $140.3 / 116.5$ & 17.32 & $162.0 \mathrm{a}$ & $145.1 / 183.2$ & 5.8 & $152.8 / 140.7$ & 14.74 \\
\hline $\mathrm{ST}, \mathrm{g} \mathrm{kg}^{-1}$ & $619.0 \mathrm{a}$ & $602.1 / 632.0$ & 1.2 & $630.5 / 612.8$ & 11.89 & $606.8 \mathrm{~b}$ & $596.3 / 618.0$ & 1.1 & $615.8 / 602.0$ & 13.70 \\
\hline BGL, $\mathrm{g} \mathrm{kg}^{-1}$ & $46.0 \mathrm{~b}$ & $40.4 / 57.2$ & 9.4 & $44.8 / 38.8$ & 3.75 & $50.0 \mathrm{a}$ & $41.0 / 63.0$ & 11.7 & $47.3 / 43.3$ & 3.34 \\
\hline
\end{tabular}

\footnotetext{
${ }^{1}$ TKW, thousand kernel weight; TW, test weight; CP, crude protein; ST, starch; BGL, $\beta$-glucans

2 HB, 'Irbe'; C, 'Ansis'

${ }^{3}$ Trait means followed by different letters are significantly different between the years at the level of $P \leq 0.05$
} 
of hulless breeding lines and a higher test weight was observed in 2010. The best hulless breeding lines according to starch content did not exceed that of the standard 'Irbe' level.

As indicated by the coefficient of variation $(\mathrm{V} \%=9.4-$ $11.7)$, the difference between minimum and maximum value of $\beta$-glucan for grains of hulless breeding lines was rather high and varied from 40.4 to $57.2 \mathrm{~g} \mathrm{~kg}^{-1}$ in 2010 and from 41.0 to $63.0 \mathrm{~g} \mathrm{~kg}^{-1}$ in 2011 . Significantly higher $(P \leq$ $0.05)$ mean value of this trait and higher phenotypic variation within breeding lines were observed in 2011. Hulless barley genotypes showed substantially higher $\beta$-glucan content compared to that of the hulled standard variety 'Ansis'. According to results in both years, there were hulless breeding lines with significantly higher $\beta$-glucan content than that of hulless standard variety 'Irbe' $\left(+12.4\right.$ and $15.7 \mathrm{~g} \mathrm{~kg}^{-1}$ compared to hulless standard variety 'Irbe'; $\mathrm{Rs}_{0.05}=3.34-$ $3.75 \mathrm{~g} \mathrm{~kg}^{-1}$ ) (Table 2).

Micronutrient content. DPPH radical scavenging activity in hulless spring barley breeding material had rather high variation in antioxidant activity, with a minimum value of $44.6 \%$ and maximum value of $80.1 \%$ (Table 2).

Table 2

VARIATION OF MICRONUTRIENT CONTENT OF HULLESS SPRING BARLEY LINES, $2010^{1}$

\begin{tabular}{l|c|c|c}
\hline Indices & $\begin{array}{c}\text { Radical scaveng- } \\
\text { ing activity, } \%\end{array}$ & $\begin{array}{c}\text { Total phenolic } \\
\text { content, mg GAE } \\
100 \mathrm{~g}^{-1} \mathrm{DW}\end{array}$ & $\begin{array}{c}\alpha \text {-tocopherol, } \\
\mathrm{mg} \mathrm{kg}^{-1}\end{array}$ \\
\hline Mean value & 64.8 & 202.6 & 5.5 \\
Min & 44.6 & 143.6 & 3.3 \\
Max & 80.1 & 262.1 & 8.7 \\
s & 9.0 & 27.1 & 1.4 \\
V\% & 13.9 & 13.4 & 25.6 \\
'Irbe' (HB) & 64.3 & 177.9 & 7.9 \\
'Ansis' (C) & 49.7 & 187.5 & 6.5
\end{tabular}

The hulled variety 'Ansis' had lower radical scavenging activity $(49.7 \%)$ than that of the hulless variety 'Irbe' (64.3\%). Total phenolic compound amount expressed as gallic acid equivalent (GAE) in hulless barley breeding material had high variation: from 143.6 to 262.1 GAE mg 100 $\mathrm{g}^{-1}$ with coefficient of variation $13.4 \%$. There was no notable difference between hulled and hulless standard varieties in content of total phenolic compounds in grain. The coefficient of variation of $\alpha$-tocopherol among hulless genotypes was high and varied from 3.30 to $7.78 \mathrm{mg} \mathrm{kg}^{-1}$. The genotypic variation in $\alpha$-tocopherol content in grain of hulless barley breeding lines was also high $(\mathrm{V} \%=25.6)$. The content of $\alpha$-tocopherol varied from 3.3 to $8.7 \mathrm{mg} \mathrm{kg}^{-1}$. Hulless standard variety 'Irbe' had a higher $\alpha$-tocopherol content in grains than the covered variety 'Ansis' (Table 2).

There were significant correlations between physical and chemical composition variables for hulless barley genotypes. In both years of investigation significant negative correlation was found between starch content and 1000 grain weight $\left(\mathrm{r}_{10}=-0.480 ; \mathrm{r}_{11}=-0.483\right)$ and crude protein $\left(r_{10}=0.720 ; r_{11}=-0.868\right)$. Positive correlation was found between crude protein and $\beta$-glucan, and in 2010 this relationship was statistically significant (Table 3).

Table 3

PHENOTYPIC CORRELATION BETWEEN PHYSICAL AND BIOCHEMICAL TRAITS OF HULLESS BARLEY ${ }^{1}$

\begin{tabular}{c|c|c|c|c|c|c|c|c}
\hline Traits $^{2}$ & TKW & TW & CP & ST & BGL & TPC & RSA & $\alpha-T$ \\
\hline TKW & 1 & 0.057 & 0.319 & $-0.483^{*}$ & -0.128 & x & x & x \\
TW & 0.177 & 1 & $-0.431^{*}$ & 0.475 & 0.148 & x & x & x \\
CP & 0.357 & -0.138 & 1 & $-0.868^{*}$ & 0.375 & x & x & x \\
ST & $-0.48 *^{3}$ & 0.346 & $-0.720^{*}$ & 1 & -0.209 & $\mathrm{x}$ & $\mathrm{x}$ & $\mathrm{x}$ \\
BGL & -0.218 & 0.038 & $0.404^{*}$ & -0.004 & 1 & $\mathrm{x}$ & $\mathrm{x}$ & $\mathrm{x}$ \\
TPC & -0.307 & 0.082 & -0.195 & 0.255 & 0.201 & 1 & $\mathrm{x}$ & $\mathrm{x}$ \\
RSA & $-0.476^{*}$ & -0.148 & -0.347 & $0.530^{*}$ & 0.327 & $0.519^{*}$ & 1 & $\mathrm{x}$ \\
$\alpha-\mathrm{T}$ & -0.002 & -0.149 & 0.081 & -0.176 & -0.171 & $-0.471^{*}$ & 0.356 & 1
\end{tabular}

${ }^{1}$ Data of 2010 below diagonal, data of 2011 above diagonal

${ }^{2}$ TKW, thousand kernel weight; TW, test weight; CP, crude protein; ST, starch; BGL, $\beta$-glucans; TPC, total phenolic content; RSA, radical scavenging activity; $\alpha$-T, $\alpha$-tocopherol

${ }^{3}$ Significant at 0.05 probability level $\left(\mathrm{r}_{0.05 ; \mathrm{n}-2}=0.381\right)$

Significant $(P<0.05)$ positive correlation was detected between total DPPH radical scavenging activity and starch content $(r=0.530)$. There was a positive significant relationship between the content of total phenolic content in barley grain dry matter and radical scavenging activity $(\mathrm{r}=$ $\left.0.519 ; \mathrm{r}_{0.05}=0.381\right)$.

A summary of genotypes with food grain physical and chemical trait values that are above the mean levels are shown in Table 4.

Several hulless barley lines provided good results according to several grain quality traits simultaneously (indicated in bold). Hulless line 'IC 360' characterized with heightened 1000 kernel weight (46.2 g), crude protein (177.3 $\mathrm{g} \mathrm{kg}^{-1}$ ) and $\beta$-glucan content $\left(53.6 \mathrm{~g} \mathrm{~kg}^{-1}\right)$ as well as total phenolic content (221.6 mg GAE $100 \mathrm{~g})$.

Table 4

EVALUATION RESULTS OF HULLESS BARLEY GENOTYPES USING SELECTION CRITERIA, mean+s (2011-2012)

\begin{tabular}{|c|c|c|}
\hline Traits & mean $+\mathrm{s}$ & Lines with trait values $\geq$ mean $+s$ \\
\hline TKW, g & 44.4 & IC 360; IC 361; 1194; 1236 \\
\hline $\mathrm{TW}, \mathrm{g} \mathrm{L}^{-1}$ & 787.2 & $1175 ; 1194 ; 1213 ;$ PR 4651 \\
\hline $\mathrm{CP}, \mathrm{g} \mathrm{kg}^{-1}$ & 168.2 & IC 360; IC 361;1216; 1226; 1244; 1217 \\
\hline ST, $\mathrm{g} \mathrm{kg}^{-1}$ & 623.7 & IC 363; 1185; 1214; PR 4651; 'Irbe’' \\
\hline BGL, $\mathrm{g} \mathrm{kg}^{-1}$ & 52.4 & IC 360; 1196; 1226; PR 4651; PR 3440(w)* \\
\hline $\begin{array}{l}\text { TPC, } \\
\text { mg GAE } 100 \mathrm{~g}^{-1}\end{array}$ & 229.8 & $\begin{array}{l}\text { IC 363; 1165; 1196; PR 3440(w) } \\
\text { (IC360/221.6; 1185/222.3) }\end{array}$ \\
\hline RSA, \% & 73.8 & $1167 ; \mathbf{1 1 8 5} ; 1189 ;$ PR 3440(w) \\
\hline$\alpha-\mathrm{T}, \mathrm{mg} \mathrm{kg}^{-1}$ & 6.9 & IC 364; 1166; 1185; 1216; 1226; 'Irbe' \\
\hline
\end{tabular}

* (w) - waxy endosperm 
Hulless barley line ' 1185 ' was selected due to high starch content $\left(624.5 \mathrm{~g} \mathrm{~kg}^{-1}\right)$ micronutrient levels - total phenolic content (222.3 mg GAE $\left.100 \mathrm{~g}^{-1}\right)$, radical scavenging activity $(80.1 \%)$ and $\alpha$-tocopherol content $\left(6.9 \mathrm{mg} \mathrm{kg}^{-1}\right)$. Hulless line 'PR 3440' with waxy endosperm showed good results of food grain quality according to grain $\beta$-glucan $\left(59.9 \mathrm{~g} \mathrm{~kg}^{-1}\right)$ content in grains, total phenolic content (234.7 $\mathrm{mg} \mathrm{GAE} 100 \mathrm{~g}^{-1}$ ) and radical scavenging activity $(76.9 \%)$

\section{DISCUSSION}

Genetic variability in the material of a breeding programme is an important resource for creation of new variety ideotypes with desired traits for increased crop production and quality.

The absence of a hull results in a $10-13 \%$ average dry weight loss, and therefore hulless genotypes are commonly known to have a lower 1000 kernel weight, higher test weight, starch content and beta-glucan content in grains than covered ones (Bhatty, 1999). The data presented in this paper demonstrate notable variation among the spring barley breeding lines in all investigated grain physical traits as well as in macronutrient and micronutrient content in the grain dry matter.

In this study, significantly higher TKW, crude protein and $\beta$-glucan was observed in 2011 than in 2010. This can be explained by differences between these two years in periods of high temperature and low precipitation. Grain weight can be influenced by grain set, which should reflect conditions around anthesis and can be also influenced by earlier conditions as well. A reduction in TKW may be not only due to abiotic and biotic stress during grain filling, but a lower grain weight could indicate also the plasticity of yield components (Fisher, 2007). In 2010, during the first part of grain filling, the weather conditions were hot and dry, which could have influenced the final grain weight. In 2011, the critical period for plant development during the generative phase occurred at the end of May and beginning of June, when set of grain number in spikes were forming. Later, this development was a prerequisite for higher grain weight due to compensation during the grain filling period when moisture conditions became optimal. Barley protein usually varies inversely with the starch content, and exhibits the greatest fluctuation among the main nutrients. Accumulation of starch is more sensitive to high temperature than is accumulation of nitrogen, which frequently determines the grain nitrogen proportion and thus protein content (Schelling et al., 2003). This effect of temperature was observed in 2011. Also, $\beta$-glucan content increases gradually during grain development, depending on variety and growing season (Aman et al., 1989).

Several types of polyphenol extraction have been described, as well as various techniques have been used for the determination of polyphenolic compounds. For barley, total polyphenol contents measured by spectrofotometric method and expressed in gallic acid equivalent/GAE have been published in the literature (Singleton et al., 1999; Zhao et al., 2008; Dabina-Bicka et al., 2011). The present study indicated that hulless barley can be a good source of phenolic compounds as TPC content ranged from 143.6 to $262.1 \mathrm{mg}$ GAE $100 \mathrm{~g}^{-1}$. The obtained values are similar to those reported by H. Zhao et al. (2008) but higher than those reported by Singleton et al. (1996). Also, similar values for TPC content of hulless barley genotypes of Latvian origin were obtained by I. Dabina-Bicka et al. (2011) and TPC content did not significantly differ between covered and hulless barley.

The results showed a positive significant relationship between total phenolic content and radical scavenging activity. Total phenolic content showed strong correlation with DPPH radical scavenging activity in spring barley (Zhao, 2008). This confirms that metabolites like phenolic compounds possess antioxidant activity and can play a preventive role in the development of cancer, heart and age related diseases. They have also been reported to be chemopreventive agents by lowering cholesterol levels and repairing damaged cells (Kahkonen et al., 1999).

Significant $(P<0.05)$ positive correlation was observed between DPPH radical scavenging activity and grain starch content. Whole and unpolished grain of hulless barley consist mainly of starchy endosperm, and hence the ratio of amylose and amylopectin content can effect not only the quality of obtained baking products but also the antioxidant activity. For example, it has been shown that high-amylose corn has better antioxidant activity than typical corn genotypes (Li et al., 2007). In our study, the only genotype 'PR 3440 ' with waxy or high-amylopectin endosperm also showed higher radical scavenging activity and total phenolic content. In the future, wider investigation of genotypes with different amylose and amylopectin ratios is needed to find donors with high content of natural antioxidant compounds.

Among cereals, barley can be a good source of tocopherols and tocotrienols, which are important phytochemical compounds with antioxidant activity and potential benefits for human health (Colombo, 2010). The hulless barley genotypes included in this study showed rather high variability in $\alpha$-tocopherol content $\left(3.3-8.7 \mathrm{mg} \mathrm{kg}^{-1}\right)$. These results were similar to those reported by Ehrenbergerova et al. (2006) study in the Czech Republic, in which the average $\mathrm{i}$-tocopherols content was $6.7 \mathrm{mg} \mathrm{kg}^{-1}$. In Italy, for hulless varieties the $\alpha$-tocopherol content was higher ( 8.4 to 10.1 $\mathrm{g} \mathrm{kg}^{-1}$ ) and for covered varieties - 8.4-8.6 $\mathrm{g} \mathrm{kg}^{-1}$ (Cavarello et al., 2004). Genotype and growing conditions are known to significantly affect the content of $\alpha$-tocopherol (Zilienski et al., 2001; Ehrenbergerova et al., 2006).

The major aim of this study was determination of hulless barley genotypes with high nutritional value. Genotypic potential exists within the hulless spring barley material included in this study. This genetic variation can be used for the development of the improved barley breeding material 
specifically designed for food with high nutritional value. The study concludes that hulless barley has antioxidant activity, which is related to the total phenolic content of the grain dry matter samples. Hence, cereal species can be a potential source of natural antioxidant, which could be useful in physiological and pathological medicine, and of interest to food manufacturing industries. The best hulless breeding lines 'IC 360' and '1185' were selected for future use in clinical investigations. Genotype 'IC 360 ', by the name 'Kornelija', in 2012 was submitted for DUS and VCU tests.

\section{ACKNOWLEDGEMENT}

This study is performed with financial support of European Regional Development Fund co-financed project No. 2DP/2.1.1.1.0/10/APIA/VIAA/083.

\section{REFERENCES}

Aman, P., Graham, H., Tilly, A. C. (1989). Content and solubility of mixed-linked $\beta$-glucan in barley and oats during kernel development and storage. J. Cereal Sci., 10, 45-50.

Bhatty, R. S. (1999) The potential of hulless barley. Cereal Chemistry, 76, 589-599.

Cavarelo, A., Gianineti, A., Finocchiaro, D. A., Stanca, A. M. (2004). Tocols in hull-less and hulled barley genotypes grown in contrasting environments. J. Cereal Sci., 39, 175-180.

Charalampopouos, D., Wang, R., Pandiella, S. S., Webb, C. (2002). Application of cereals and cereal components in functional foods: A review. Int. J. Food Microbiol., 79 (1-2), 131-141.

Colombo, M. L. (2010). An update on vitamin E, tocopherol and tocotrienol-perspectives. Molecules, 15, 2103-2113.

Dabina-Bicka, I., Karklina, D., Kruma, Z. (2011). Polyphenols and vitamin $\mathrm{E}$ as potential antioxidants in barley and malt. Proceedings of 6th Baltic Conference on Food Science and Technology: Innovations for Food Science and Production, FOODBALT-2011, 5-6 May, 2011 (pp. 121-126). Jelgava.

Evers, T., Millar S. (2002). Cereal grain structure and development: Some implications in quality. J. Cereal Sci., 36, 261-284.
Ehrenbergerova J., Belcrediova, N., Pryma, J. K., Newman, C. W. (2006) Effect of cultival, year grown, and croping system on the content of tocopherols and tocotrienols in grains of hulled and hulless barley. Plant Foods Human Nutr., 61 (3), 145-150.

Falk, J., Krahnstover, A., van der Kooij, T. A., Schlensog, M., Krupinska, K. (2004). Tocopherol and tocotrienol accumulation during development of caryopses from barley (Hordeum vulgare L.). Phytochemistry, 65 (22), 2977-2985.

Fisher, R. A. (2007). Understanding the physiological basis of yield potential in wheat. J. Agricult. Sci., 145, 99-113.

Grissom, R. J., Kim, J. J. (2012). Effect Sizes for Research: Univariate and Multivariate Applications. 2nd ed. New York: Taylor \& Francis Group. 429 pp.

Kahkonen, M. P., Hopia, A. I., Vuorela, H. J., Rauha, J., Pihlaja, K., Kujala, S. T., Heinonen, M. (1999). Antioxidant activity of plant extracts containing phenolic compounds. J. Agricult. Food Chem., 47, 3954-3962.

Li, W., Wei, C. V., White, P. J., Beta, T. (2007). High-amylose corn exhibits better antioxidant activity than typical and waxy genotypes. J. Agricult. Food Chem., 55 (2), 291-298.

Moreau, R. A., Flores R. A., Hicks K. B. (2007). The composition of functional lipids in hulled and hulless barley, in fractions obtained by scarification, and in barley oil. Cereal Chem., 84, 1-5.

Newman, R. K., Newman, C. W. (2008). Barley for Food and Health. Science, Technology, and Products. A John Willey\&Son, Inc. 245. pp.

Pins, J. J., Kaur H. (2006). A review of the effects of barley $\beta$-glucan on cardiovascular and diabetic risk. Cereal Foods World, 51, 8-12.

Ragaee, S., Abdel-Aal, E.-S. M., Noaman, M. (2006) Antioxidant activity and nutrient composition of selected cereals for food use. Food Chem., 98 (1), 32-38

Rice-Evans, C. A., Miller, N. J., Bolwell, P. G., Bramley. P. M, Pridh, J. B. (1995). The relative antioxidant activities of plant-derived polyphenolics flavonoids. Free Radical Res., 22, 375-383.

Schelling, K., Born, K., Weissteiner, C., Kunbauch W. (2003). Relationships between yield and quality arameters of barley (Hordeum vulgare L.) and phenological and meteorological data. J. Agron. Crop Sci., 189, 113-122.

Singleton, V. L., Orthofer, R., Lamuela-Raventos, R. M. (1999). Analysis of total phenols and other oxidation substrates and antioxidants by means of Folin-Ciocalteu reagent. Meth. Enzymol., 29, 152-178.

Zhao, H., Fan, W., Dong, J., Lu, J., Chen, J., Shan, L., Lin, Y., Kong, W. (2008). Evaluation of antioxidant activities and total phenolic contents of typical malting barley varieties. Food Chem., 107, 296-304

Zielinski, H., Ciska, E., Kozlowska, H. (2001). The cereal grains: Focus on vitamin E. Czech J. Food Sci., 19, 182-188

\section{FIZIKĀLO UN BIOK̦ĪMISKO PAZĪMJU RAKSTUROJUMS KAILGRAUDU VASARAS MIEŽU GRAUDIEM LATVIJAS SELEKCIJAS PROGRAMMĀ}

Pilngraudu izejvielu, kā piemēram, kailgraudu miežu izmantošana veselīgas diētas sabalansēšanai var veicināt profilaksi sirds un asinsvadu saslimšanu, diabēta un specifisku vēža formu ierobežošanai. Pētījuma mērḳis bija novērtēt kailgraudu paraugus no Latvijas miežu selekcijas materiāla pēc graudu fizikālajām un biokīimiskajām pazīmēm. Lauka izmēǵinājumi iekārtoti Valsts Stendes Graudaugu selekcijas institūtā no 2010. gada līdz 2011. gadam. Pētījumā iekḷautajām 29 vasaras miežu kailgraudu līnijām analizēta 1000 graudu masa, tilpummasa, kopproteīna, cietes, $\beta$-glikānu, kopējais fenolu saturs, $\alpha$-tokoferolu saturs un antiradikālā aktivitāte. Graudu fizikālo un biokīmisko pazīmju mainību galvenokārt ietekmēja genotips $\left(\omega^{2}=32-62 \%\right)$ un gads $\left(\omega^{2}=8-42 \%\right)$, bet mazākā mērā - šo faktoru mijiedarbība. Kailgraudu miežu materiālam konstatēta augsta genotipiskās mainība pēc kopējā fenolu satura, antiradikālās aktivitātes un $\alpha$-tokoferolu satura graudos $(\mathrm{V} \%=13.4-25.6)$. Būtiska $(P<0.05)$ pozitīva korelācija noteikta starp antiradikālo aktivitāti un kopējā fenolu $(\mathrm{r}=0.519)$ un cietes saturu graudos $(r=0.530)$. Labākos rezultātus pēc analizētajām pazīmēm nodrošināja kailgraudu miežu selekcijas līnijas '1185' un 'IC 360' (iesniegta AVS un SĪN pārbaudei ar šḳirnes nosaukumu 'Kornelija'), kas iekḷautas klīniskajos pētījumos. 